\title{
Evaluation of the depth of the Pantanal sedimentar basin based on seismic events
}

\author{
Avaliação da profundidade da bacia sedimentar do Pantanal com base em eventos sísmicos \\ Evaluación de la profundidad de la cuenca sedimentaria del Pantanal basada en eventos sísmicos
}

Received: 07/14/2021 | Reviewed: 07/19/2021 | Accept: 07/27/2021 | Published: 08/03/2021

Amanda Letícia Abegg da Silveira

ORCID: https://orcid.org/0000-0001-9063-8793

Universidade Federal de Mato Grosso do Sul, Brazil E-mail: abegg.geo@gmail.com

Gustavo Marques e Amorim

ORCID: https://orcid.org/0000-0002-8321-325X

Universidade Federal de Mato Grosso do Sul, Brazil

E-mail: gustavo m amorim@hotmail.com

Dhonatan Diego Pessi

ORCID: https://orcid.org/0000-0003-0781-785X

Universidade Federal de Mato Grosso do Sul, Brazil

E-mail: dhonatan.pessi@gmail.com

Normandes Matos da Silva

ORCID: https://orcid.org/0000-0002-4631-9725

Universidade Federal de Rondonópolis, Brazil E-mail: normandes@ufr.edu.br

Camila Leonardo Mioto

ORCID: https://orcid.org/0000-0002-6951-9527

Universidade Federal de Rondonópolis, Brazil E-mail: ea.mioto@gmail.com

Andrey Gaspar Sorrilha Rodrigues

ORCID: https://orcid.org/0000-0003-0149-1596 Universidade Federal de Mato Grosso do Sul, Brazil

E-mail: andreygaspar@gmail.com

Valdiney Rodrigues Pedrozo Júnior

ORCID: https://orcid.org/0000-0001-6962-7547 Universidade Federal de Mato Grosso do Sul, Brazil E-mail: valdineyjr@gmail.com

Antonio Conceição Paranhos Filho

ORCID: https://orcid.org/0000-0002-9838-5337 Universidade Federal de Mato Grosso do Sul, Brazil E-mail: antonio.paranhos@ufms.br

Rômulo Machado

ORCID: https://orcid.org/0000-0002-9448-8937 Universidade de São Paulo, Brazil E-mail: rmachado@usp.br

\begin{abstract}
The main objective of this study is qualify the seismic activities captured at the Santo Antônio do Leverger seismic station (SALV), state of Mato Grosso, Brazil. The choice of this station was due to its location in the northern portion of the Pantanal Sedimentary Basin, considered historically as one of the seismogenic regions of Brazil. The methodology involved downloading the files through the poet.py script, where the events were identified, selected and stored within $440 \mathrm{~km}$ from the SALV station. Once confirmed, filtrations were applied using the Butterworth method. This method minimizes the loss of information recorded by events that have occurred. Thus, most events indicate disagreement with the applied filters, demonstrating that there is a structure that influences the propagation of the wave, changing its original speed and frequency. The triggering method was applied to the behavior of seismic waves that crossed the sedimentary interval of the Pantanal Basin. The results were plotted on maps, overlaid in the form of sub-regions of the Pantanal using the QGIS geoprocessing software, in which the geological contacts were determined. Thus, it was possible to observe that each sub-region presents a different profile for each event, with sub-regions that tend to increase the signal's acceleration, maintain it or slow it down.
\end{abstract}

Keywords: Earthquake triggering; Seismic profile; Pantanal tectonics.

\section{Resumo}

O principal objetivo deste estudo é entender e qualificar as atividades sísmicas capturadas na estação sísmica de Santo Antônio do Leverger (SALV), estado de Mato Grosso, Brasil. A escolha desta estação deveu-se à sua localização na porção Norte da Bacia Sedimentar do Pantanal, considerada historicamente como uma das regiões sismogênicas do 
Brasil. A metodologia envolveu o download dos arquivos através do script poet.py, onde os eventos foram identificados, selecionados e armazenados em até $440 \mathrm{~km}$ da estação SALV. Uma vez confirmados foram aplicadas filtragens utilizando o método de Butterworth. Este método minimiza a perda de informações registradas pelos eventos ocorridos. Assim, a maioria dos eventos indica desacordo com os filtros aplicados, demonstrando que existe uma estrutura que influência na propagação da onda, alterando sua velocidade e frequência originais. O método 'triggering' foi aplicado ao comportamento das ondas sísmicas ao atravessaram o intervalo sedimentar da Bacia do Pantanal. Os resultados foram plotados em mapas, sobrepostos na forma de sub-regiões do Pantanal utilizando o software de geoprocessamento QGIS,no qual foram determinados os contatos geológicos. Desta forma foi possível observar que cada sub-região apresenta um perfil diferente para cada evento, com sub-regiões que tendem a aumentar a aceleração do sinal, mantê-lo ou abrandá-lo.

Palavras-chave: Gatilhamento de terremotos; Perfil sísmico; Tectônica do Pantanal.

\section{Resumen}

El objetivo principal de este estudio es comprender y calificar las actividades sísmicas capturadas en la estación sísmica Santo Antônio do Leverger (SALV), estado de Mato Grosso, Brasil. Esta estación fue elegida por su ubicación en la parte Norte de la Cuenca Sedimentaria del Pantanal, históricamente considerada una de las regiones sismogénicas de Brasil. La metodología consistió en descargar los archivos a través del script poet.py, donde los eventos fueron identificados, seleccionados y almacenados dentro de los $440 \mathrm{~km}$ de la estación SALV. Una vez confirmado, se aplicaron filtraciones mediante el método Butterworth. Este método minimiza la pérdida de información registrada por los hechos ocurridos. Así, la mayoría de eventos indican desacuerdo con los filtros aplicados, demostrando que existe una estructura que influye en la propagación de la onda, cambiando su velocidad y frecuencia originales. El método de 'activación' se aplicó al comportamiento de las ondas sísmicas al atravesar el intervalo sedimentario de la Cuenca del Pantanal. Los resultados fueron graficados en mapas, superpuestos en forma de subregiones del Pantanal utilizando el software de geoprocesamiento QGIS, en el cual se determinaron los contactos geológicos. Así, se pudo observar que cada subregión presenta un perfil diferente para cada evento, con subregiones que tienden a incrementar la aceleración de la señal, mantenerla o ralentizarla.

Palabras clave: Desencadenante de terremotos; Perfil sísmico; Tectónica del Pantanal.

\section{Introduction}

The Brazilian Seismic Network (RSBR) continuously monitors the seismic activity in all regions of Brazil, improving the studies aimed at the detection of plate tectonic movements (Pirchiner et al., 2011). The seismic data record suggests the existence of active faults in the Pantanal, which is historically considered as one of the seismogenic regions of Brazil (Branner, 1912; Soares et al., 1998). Some of these faults are possibly of a strike-slip fault, judging by the results obtained from earthquake focal mechanisms, which suggest approximately E-W compression (Ussami et al., 2000; Assumpção et al., 2016). Several authors have associated the occurrence of seismic activity in the Pantanal with recent tectonic reactivation linked to the Transbrazilian Lineament (Schobbenhaus et al., 1975; Soares et al., 1998; Riccomini e Assumpção, 1999; Assine e Soares, 2004; Facincani et al., 2011, 2012; Dias et al., 2016), a crustal scale NE-SW structure of Precambrian age. This structure has been related to a seismic zone that could have continuity with the seismic band of Goiás-Tocantins (Assine, 2004).

When studying earthquakes that have occurred in the Pantanal, Dias et al. (2016) observed a focal depth between 5 to $6 \mathrm{~km}$, being therefore located in the upper crust, within the Precambrian basement, and for that reason reject their relationship with the aforesaid lineament. Recently, it has been mentioned that some of the earthquakes that have occurred in the southern part of the Pantanal may be due to the emplacement and development of the Taquari Megafan (Oliveira et al., 2018). Another possibility is that such earthquakes are triggered by the action of the overpressure produced by the increase in the volume of water during the flood periods in the region, thereby increasing the internal pressure in the pores of the rocks and consequently reducing the coefficient of friction between the grains, thus potentiating the formation of induced earthquakes.

Neotectonics have played a key role in the conditioning of the main rivers of the Pantanal, and consequently in the entire watershed, showing drainage patterns that are frequently rectilinear with abrupt changes at right angles, that are characteristic of structural control, with the watersheds always displaying asymmetric patterns (Paranhos Filho et al., 2018; Oliveira et al., 2018). According to the authors, most of the rivers in the Pantanal follow the E-W orientation, changing the direction N-S only at the 
edges, as in the case of the Paraguay River.

The Pantanal Basin corresponds to an elongated tectonic depression similar to a graben (Assine \& Soares, 2004), with a general N-S orientation, being surrounded to the east by the Gondwanic Escarpment of the Paraná Basin, to the west by Precambrian metamorphic rocks, and to the south by Precambrian/Neopaleozoic limestones of the Serra da Bodoquena. The faults present in the western part of the basin were initially described based on geomorphological observations by Almeida (1945, 1965) and were later confirmed, including through the use of remote sensing (Paranhos Filho et al., 2013).

There are internal structures in the Pantanal Basin, such as the lineament of the Black River, which delimits the Nhecolândia region to the south, where hundreds of ponds are aligned NE-SW (62.49\%) and stand out in the Pantanal landscape, suggesting control by structures that reflect zones of weakness in the substrata of the basin (Oliveira et al., 2018). This lineament is the extension of structures in the Bolivian territory associated with the Tucavaca Belt (Litherland et al., 1989; Sousa, 2017; Oliveira et al., 2018), which were reactivated after the Pantanal Basin was emplaced.

Structural lineaments visually extracted from satellite images (CBERS-2B, WFI sensor, wide field chamber), together with field surveys performed on Precambrian and Paleozoic rocks that surface around the basin, show the existence of three directions that affect the sedimentary sequence of the basin: N-E, N-W, and E-W. This latter direction is considered the youngest and was reactivated during the Quaternary (Paranhos Filho et al., 2013).

The tectonic model adopted for the Pantanal Basin, based on terrestrial geophysical data, relates its formation to the last compressive event associated with the Andean orogeny, but its continued development was related to extensional forces that occurred in the flexural arch (forebulge) of the foreland basin of Chaco (Ussami \& Shozo, 1999). According to these authors, the subsidence model of the basin is similar to that of intracratonic basins, that is, a model of developed basins that are very distant from any plate boundary, in response to forces not located near or immediately below them. For Assine (2004), the subsidence model of the basin was not of the flexural type, as suggested by the isopaca map, but its structure was controlled by faults as already pointed out by Almeida (1945) and Freitas (1951). More recently, Assine et al. (2015) suggest that the basin origin of the was associated with uplift events occurring in southeastern Brazil.

In this context, this article aims to understand and qualify comparatively the seismic records registered at the Santo Antônio do Leverger seismographic station (SALV), located in the municipality of the same name, in the state of Mato Grosso, which have been correlated with s seismic activity at estimated depths and located in the sedimentary succession of the Pantanal Basin.

\section{Methodology}

In the context of capability inherited from the BRASIS Network, the State of Mato Grosso do Sul has three permanent seismographic stations: Aquidauana (AQDA), Sonora (PP1A), and Chapadão do Sul (C2SB), as well as other recently established stations of interest that surround the area of study, such as PTLB (Pontes e Lacerda - MT), SALV (Santo Antônio do Leverger MT), MURT (Porto Murtinho - MS), BDQN (Bodoquena - MS), AMBA (Amambai - MS), ANTJ (Antônio João - MS), CCRS (Cáceres - MT), PANT (Pantanal/Corumbá - MS), POCN (Poconé - MT), RPRD (Ribas do Rio Pardo - MS), and RVDE (Rio Verde - MS) (Figure 1). 
Figure 1 - Stations that make up the Brazilian Seismographic Network - RSBR and stations of interest for the Pantanal region. Modified from Mioto et al. (2012) and Rgeotec (2012). Image of Landsat 8 satellite (NASA, 2017).

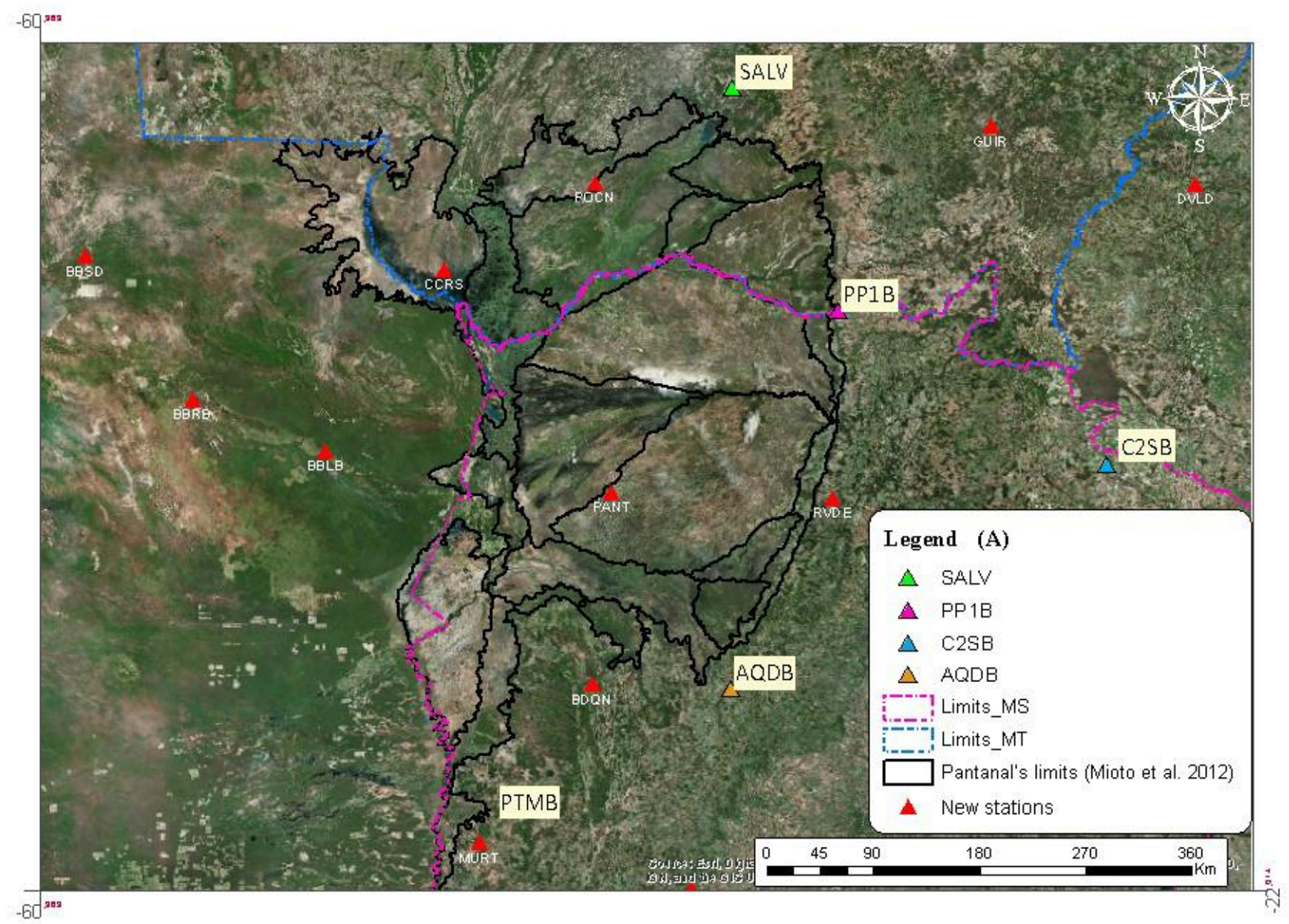

Source: Authors.

As previously mentioned, Pantanal is a tectonically active Cenozoic sedimentary basin, positioned in the Upper Paraguay River Basin, central west region of Brazil (Figure 2). 
Figure 2 - Map of seismogenic zones combined with the map of earthquakes registered in the South American and Brazilian continental shelf, between the years of 1720 and 2013. The area of the Pantanal Sedimentary Basin is shown in detail (USP, 2013).

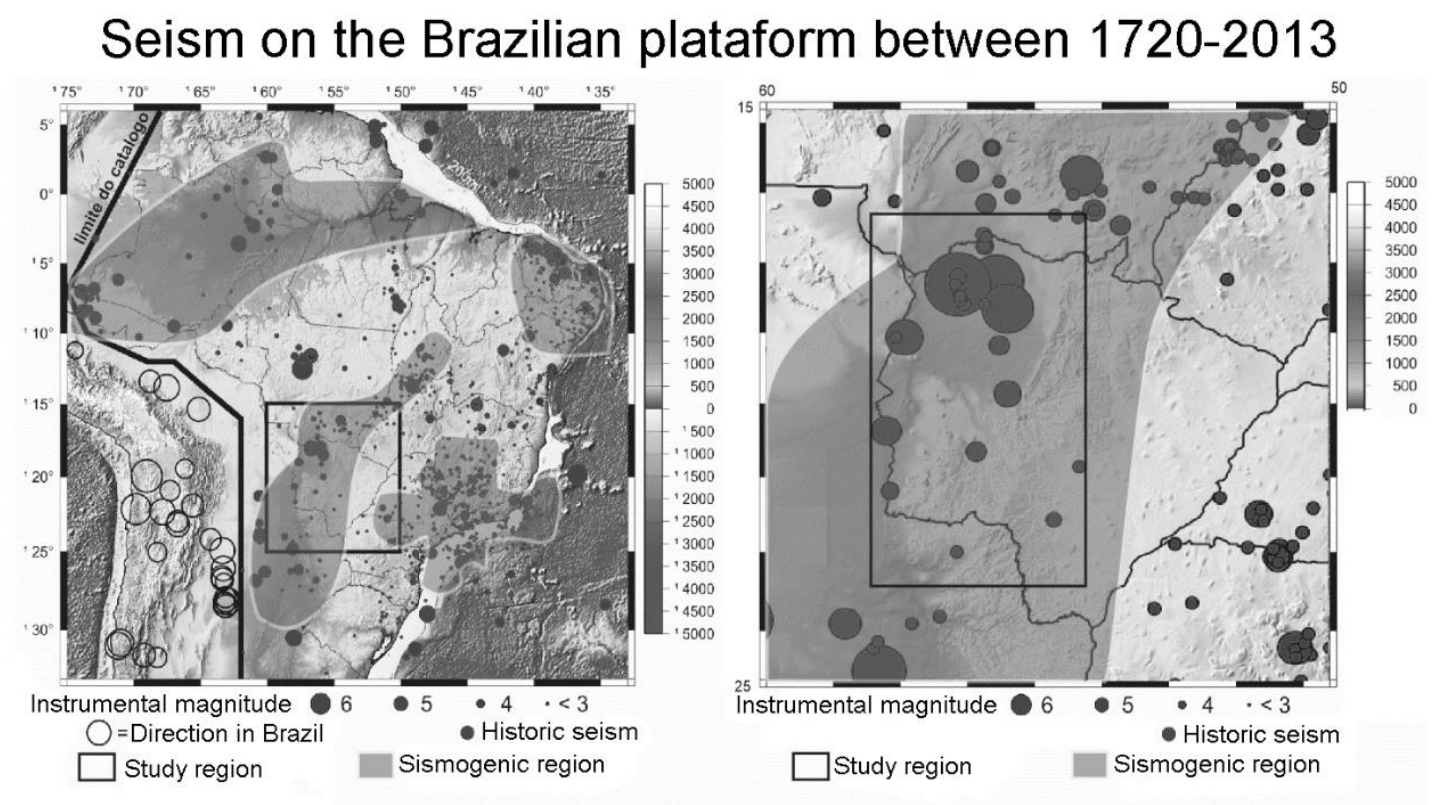

Source: Authors.

The Santo Antônio do Leverger - MT (SALV) station is composed of a high-sensitivity, wideband sensor, Trillium 120PA (Streckeisen / STS-2), with flat response in the range of 120s to $50 \mathrm{~Hz}$. The recorder is a Taurus brand model 2569 , whose flexibility to access and transmit quality controlled seismic data is done locally or via the internet, as well as the associated GPS receivers, solar panels, and satellite signal antenna (Nanometrics, 2010). The SALV seismic station is in full operation and provides seismic records of relative quality and quantity in the three N-E-Z axes. To better understand this condition of relativity, it is necessary to identify the type of signal that is being effectively registered and the type of event to which it refers.

The main application used was the Seisgram2k software (LOMAX, 2011), in which the days that had events were separated, and from which each type of earthquake (regional, local, teleseism) were observed and classified. After this, the following parameters were determined important in understanding the characteristics of the event: (1) amplitude of both wave types (primary - P and secondary -S); (2) distance from the epicenter; and (3) period and arrival times of $\mathrm{P}$ and $\mathrm{S}$ waves.

There are subprograms or scripts associated with the use of this software that aid in the automation of the data selection process, such as the Python ObsPy Earthquake Tool - Poet (Collaço, 2016). These programs allow users to consult, list and store locally informed data from the Brazilian seismic bulletin, using unique command lines. Other resources used for the development of this work were: the free software SeisGram2k, developed for the purpose of seismic studies (Lomax, 2011); Amplitude filter, a type of filtering used in the wave processing available in SeisGram2k, which allows classifying events into types and the phase division (Selesnick \& Burrus, 1998); and QGIS, a free geoprocessing software (QGIS Development Team, 2013).

The methodology involved downloading the files through the poet.py script (Collaço, 2016), which was performed at the Ubuntu command terminal (Thomas et al., 2009). This makes it easy to search for events by filtering them by date and magnitude and storing them in SAC format, the native reading format in the SeisGram2k software. In addition to identifying types of events, local and regional events of short distance or up to 4 degrees distance from the SALV station (440 km) were selected and stored in this study. 
The definition of which type of event would be selected was based on two factors: (1) distance; and (2) filtering value, and from this, it can be observed if the event presents a clearer signal with less noise. In these cases, we observed only the vertical displacement of the event, i.e., the $\mathrm{Z}$ component, since it is in this component that the displacement and the epicentral depth of the earthquake can be verified. However, it transpires that many of the stations in the RSBR network, such as SALV, for example, cannot accurately measure depth values. Due to this limitation, it was decided to prevent cumulative errors and attribute the depth of 0 to $10 \mathrm{~km}$. In this case, the value attributed reflects a surface value, or a maximum depth of $10 \mathrm{~km}$, being much closer to the surface $(1 \mathrm{~km})$ than to greater depths.

In the original seismogram, real events can be confirmed or discarded, and the Butterworth filter values with ranges varying from 0.1 to $15 \mathrm{~Hz}$ as well can define which type of events were effectively visualized, regardless of the seismic epicentral distance. The present study used filters between $0.7 \mathrm{~Hz}$ and $1.3 \mathrm{~Hz}$ for "Teleseism", between 2-5 Hz and 5-10 Hz for "Regional", and between 5-10 Hz and 10-15 Hz for "Local" (Figure 3). If the events were confirmed as local-regional, the process of "triggering" or "PeakWin" was started, which consists of converting each point of a trace to an absolute value of peak amplitude in a given time window, considering the specific mean width of the trace at the point prior to the sampled data point. In a simplified way, the "triggering" creates a reading of data points, taking into account a specific time window of 1 second and generating with this procedure a new line (Figures 4 and 5).

Figure 3 - Differences presented in the visualization of seismograms when local and regional filters are applied, which show the elastic waves produced by a seismic event. In this case, the filter better highlights the phases of the recorded seismic waves and avoids the confirmation of false positives or replicates of seismic waves related to distant events. In the example, from the responses obtained, there is more compatibility with local> regional filter values.

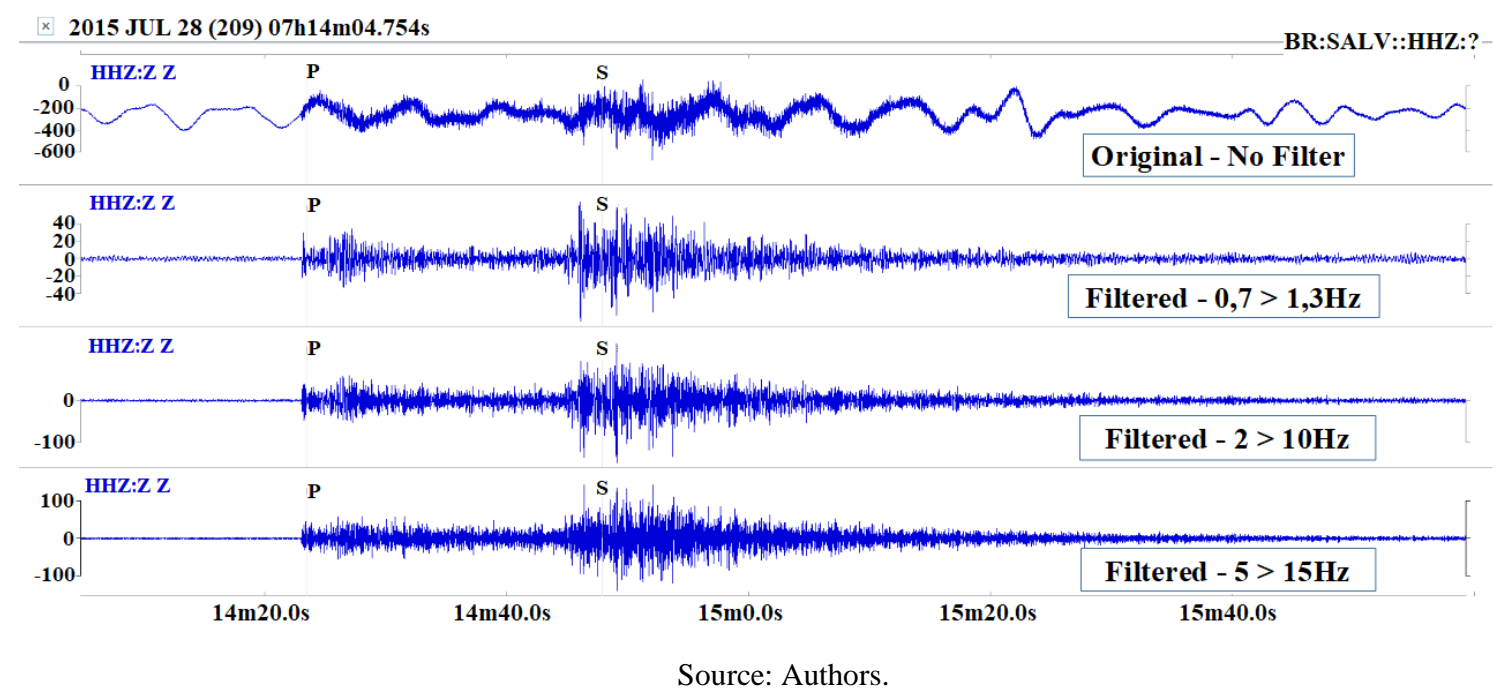


Figure 4 - Example of 'triggering' applied to the elastic waves related to the seismic event, showing the variations that occur in the filtering values tested in Figure 3. In this event, the triggers were marked, which are sets of waves at vector speed, that is, waves that represent average speed zones obtained in the Seisgram software.

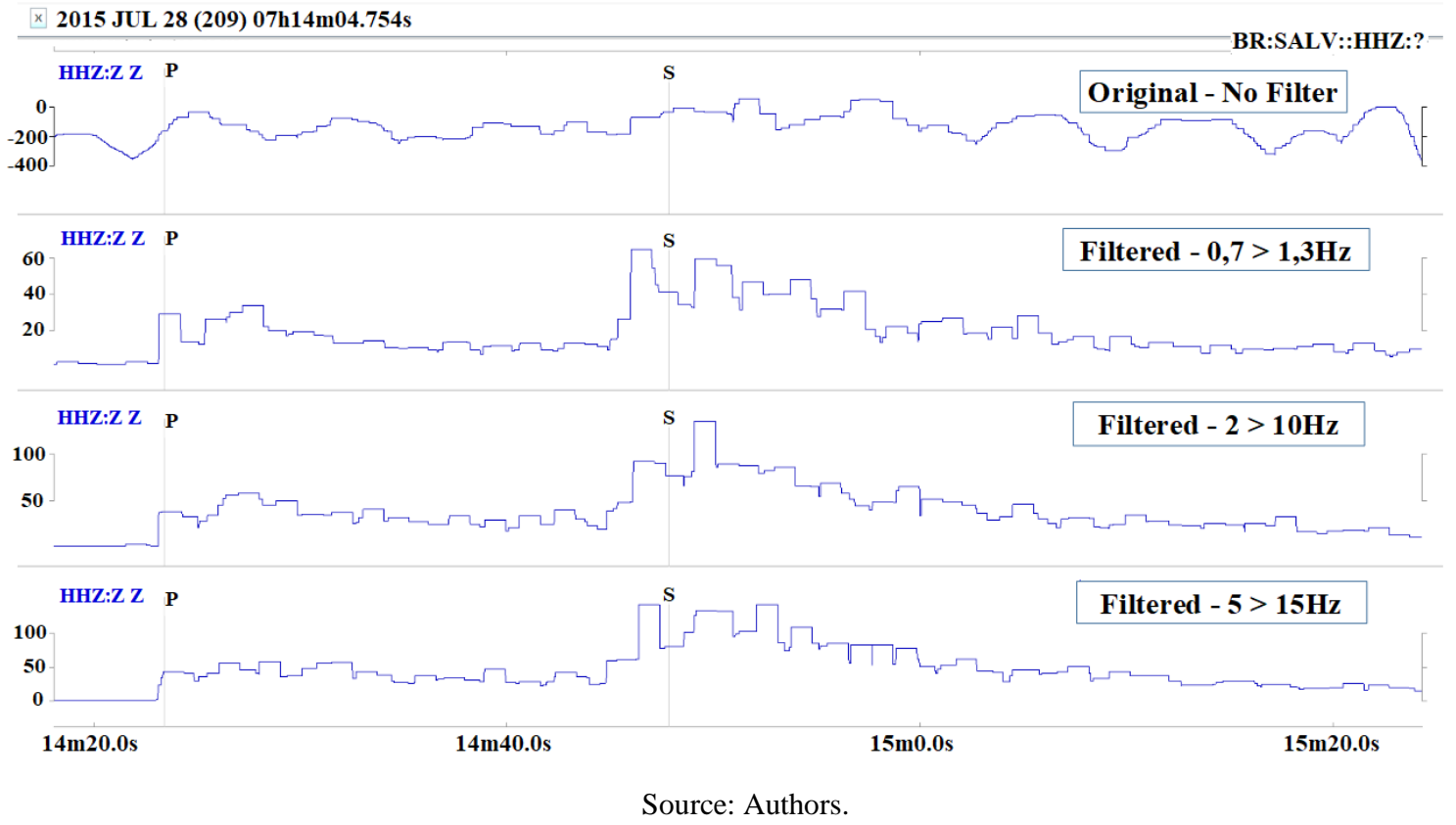

Figure 5 - Triggering' applied to the event exemplified in Figures 3 and 4, showing the variations that occur with each of the active filtering values in the details of the $3 \mathrm{~Hz}$ and $5 \mathrm{~Hz}$ values.

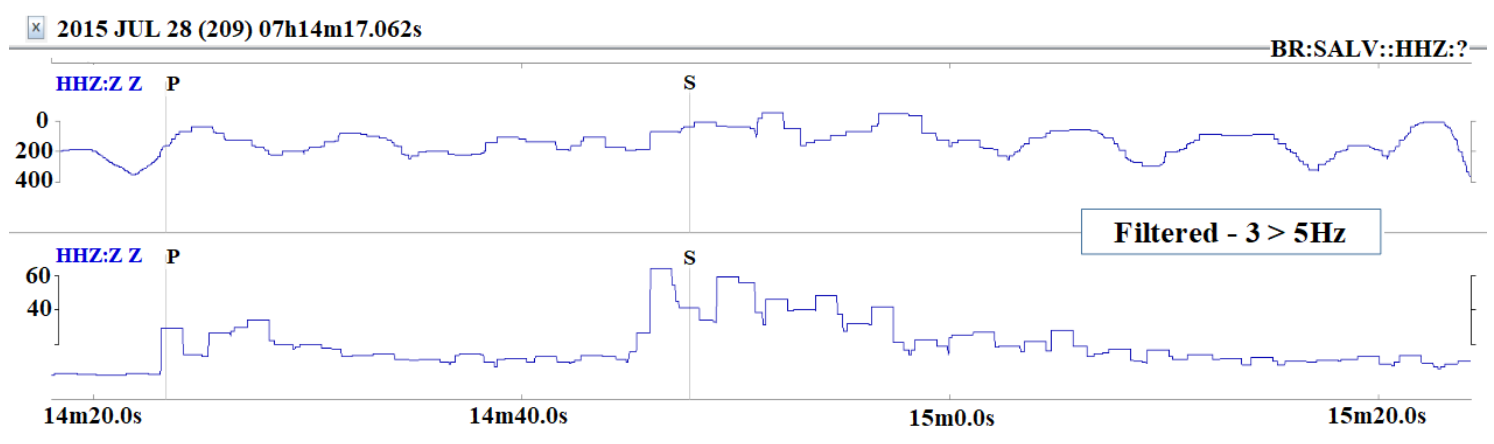

Source: Authors.

In the case of confirmed events, the sets of triggers were marked (showing the average changes of speed, phase velocity, group, etc.), and later images of the treated event were saved. These were imported into QGIS (QGIS Development Team, 2013) and georeferenced using the coordinates of the station and the epicenter of the event, combining these with the geological map, in order to test the efficiency of the method in revealing aspects of the substrata through which the seismic wave passed.

\section{Results and Discussion}

The choice of test events was based on the list of events resulting from the use of the poet script (Collaço, 2016). After the initial verification and selection in this list, a check of the list of informed events was done, retaining the confirmed events that passed correctly through the filter, and excluding the "false epicenters" or events that were confirmed with local filter values, but whose epicenter were classified as teleseism (Table 1). 
Table 1 - Examples of recording the arrival of elastic waves related to events confirmed in local filtering values, which have an epicenter too distant to be maintained in this classification.

\begin{tabular}{|c|c|c|c|c|c|c|c|c|c|c|}
\hline Year & Month & Day & Hour & Minute & Lat & Long & Mag & Local \\
\hline $\mathbf{2 0 1 3}$ & 11 & 3 & $11 \mathrm{~h}$ & $41 \mathrm{~m}$ & -5.4853 & -36.1397 & 2,1 & Pedra Preta \\
\hline $\mathbf{2 0 1 3}$ & 11 & 3 & $11 \mathrm{~h}$ & $39 \mathrm{~m}$ & -5.4825 & -36.1381 & 2,4 & Pedra Preta \\
\hline $\mathbf{2 0 1 3}$ & 10 & 29 & $15 \mathrm{~h}$ & $17 \mathrm{~m}$ & -5.3907 & -36.1167 & 3,4 & Pedra Preta \\
\hline $\mathbf{2 0 1 4}$ & 4 & 27 & $12 \mathrm{~h}$ & $51 \mathrm{~m}$ & -5.9090 & -36.5557 & 2,2 & Santana dos Matos \\
\hline $\mathbf{2 0 1 4}$ & 4 & 27 & $12 \mathrm{~h}$ & $45 \mathrm{~m}$ & -5.9071 & -35.5676 & 1,8 & Sao Pedro \\
\hline $\mathbf{2 0 1 4}$ & 5 & 15 & $15 \mathrm{~h}$ & $3 \mathrm{~m}$ & -10.4102 & -48.9141 & 3 & Pugmil \\
\hline $\mathbf{2 0 1 4}$ & 5 & 28 & $19 \mathrm{~h}$ & $48 \mathrm{~m}$ & -31.7036 & -52.4364 & 2,4 & Capão do Leão \\
\hline $\mathbf{2 0 1 5}$ & 5 & 9 & $14 \mathrm{~h}$ & $51 \mathrm{~m}$ & -22.9068 & -44.4090 & 1,8 & Angra dos Reis \\
\hline $\mathbf{2 0 1 5}$ & 5 & 15 & $16 \mathrm{~h}$ & $10 \mathrm{~m}$ & -22.9051 & -44.4162 & 2,2 & Angra dos Reis \\
\hline $\mathbf{2 0 1 5}$ & 7 & 29 & $18 \mathrm{~h}$ & $57 \mathrm{~m}$ & -11.6508 & -47.5303 & 2,1 & Natividade \\
\hline $\mathbf{2 0 1 5}$ & 7 & 29 & $10 \mathrm{~h}$ & $8 \mathrm{~m}$ & -3.2703 & -40.4370 & 2,1 & RJ \\
\hline $\mathbf{2 0 1 5}$ & 10 & 16 & $19 \mathrm{~h}$ & $45 \mathrm{~m}$ & -3.8225 & -40.5225 & 1,3 & Senador \\
\hline $\mathbf{2 0 1 5}$ & 10 & 9 & $15 \mathrm{~h}$ & $12 \mathrm{~m}$ & -13.4950 & -48.6906 & 2,7 & Cariré \\
\hline $\mathbf{2 0 1 5}$ & 10 & 9 & $15 \mathrm{~h}$ & $10 \mathrm{~m}$ & -5.3690 & -38.9202 & 2,3 & Trombas \\
\hline
\end{tabular}

In general, most of the events show disagreement with the filters applied at this station. A possible correlation is the presence at depth of large igneous bodies, such as a stock, batholith or a large sill, which is in direct contact with the basement. In this situation, the seismic waves can reflect diffracted or refracted seismic waves, resulting in a change in the origin of the original signals, because they change their initial velocity and frequency.

In the analysis of the treated data, it was noticed that the data for the year 2013 exhibited problems in the capture of waves, since many events were registered without spectral signature or were corrupted files. In this case, the records of the events appear with divided signals, making it impossible to analyze them.

In the records for the year 2014, there was a significant improvement in the quality of the records, without total loss of spectral signature. However, there was a large reduction of confirmed events in relation to those recorded. Between September and December of the same year, there was a remarkable sequence of 78 reported and unregistered events.

In the 2015 records, there was a sequence of 76 reported and unrecorded events between the period from January 1 to May 6. In the 2016, the instrumental failure was corrected and $100 \%$ of the reported events were recorded.

In 2017, with the increase in the number of reported-recorded events, there is a significant increase in the number of events recorded-confirmed, reaching the minimum percentage of $40 \%$. However, despite showing a significant sequence of events had occurred, which indicate epicenters in the Municipality of Vargem Grande, in the State of Maranhão, these should have been received and classified as seisms, instead of being classified as Local or Regional.

Confirmation of the significant improvement in reception quality coincides with the information found on the official website of the Brazilian Seismographic Network-RSBR, where it is verified that the SALV station provides data "completeness" with failure or gaps in its reception for the years 2013, 2014, and 2015, whereas it is close to $100 \%$ for 2016 and 2017 (Table 2 , Figures 6, 7, and 8). 
Table 2 - Results of the analysis of the seismic events surveyed for the Santo Antônio do Leverger station (SALV) in the approximate period of five years (2013-2017).

\begin{tabular}{|c|c|c|c|c|c|c|c|c|c|}
\hline Year & Informed (I) & $\begin{array}{c}\text { Registered } \\
(\mathbf{R})\end{array}$ & Confirmed (C) & $\begin{array}{c}\text { (I) /(R) } \\
\boldsymbol{\%}\end{array}$ & $\begin{array}{c}(\mathbf{I}) /(\mathbf{C}) \\
\boldsymbol{\%}\end{array}$ & $\begin{array}{c}\text { (I) /(R) } \\
\boldsymbol{\%}\end{array}$ & $\begin{array}{c}\text { Average } \\
\text { Mag }\end{array}$ & $\begin{array}{c}\text { Mag } \\
\text { Max }\end{array}$ & $\begin{array}{c}\text { Mag } \\
\text { Min }\end{array}$ \\
\hline $\mathbf{2 0 1 3}$ & 64 & 29 & 10 & $45 \%$ & $16 \%$ & $34 \%$ & 2,4 & 3,4 & 1,2 \\
\hline $\mathbf{2 0 1 4}$ & 242 & 164 & 66 & $68 \%$ & $27 \%$ & $40 \%$ & 2,4 & 3,5 & 0,5 \\
\hline $\mathbf{2 0 1 5}$ & 204 & 127 & 50 & $62 \%$ & $25 \%$ & $39 \%$ & 2,4 & 3,5 & 0,6 \\
\hline $\mathbf{2 0 1 6}$ & 209 & 209 & 63 & $100 \%$ & $30 \%$ & $30 \%$ & 2,4 & 3,5 & 0,7 \\
\hline $\mathbf{2 0 1 7}$ & 20 & 20 & 8 & $100 \%$ & $40 \%$ & $40 \%$ & 2,7 & 3,4 & 1,5 \\
\hline
\end{tabular}

Source: Authors.

Figure 6 - Total graph of all seismic events analyzed for the five-year period from 2013 to 2017 for the Santo Antônio do Leverger station (SALV). In this case, the events reported are indicated in the Brazilian Seismic Catalog. The events recorded provide data that are consistent with those reported, while the Confirmed events are those that provide specific records of the events that occurred.

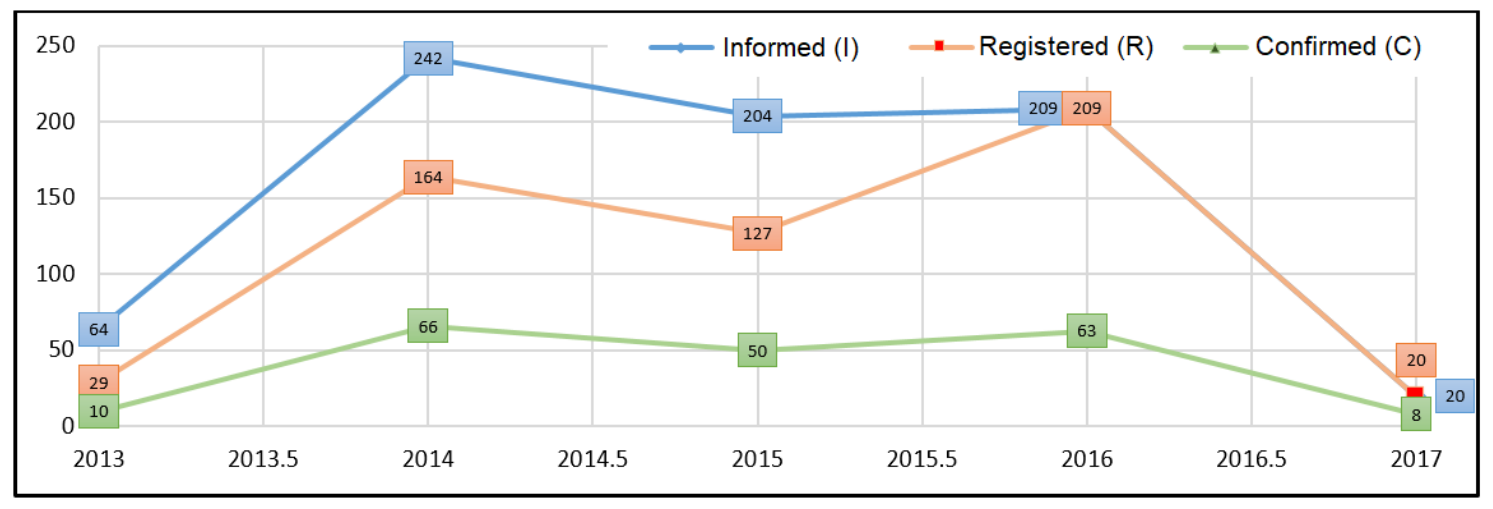

Source: Authors.

Figure 7 - Total graph of all seismic events analyzed for the five-year period between the years of 2013 to 2017 for the Santo Antônio do Leverger station (SALV). In this case, we present the percentage correlation between the Informed and Registered, Informed and Confirmed Events, in addition to the Registered and Confirmed Events. In all cases, there is a linear growth in the effective rates.

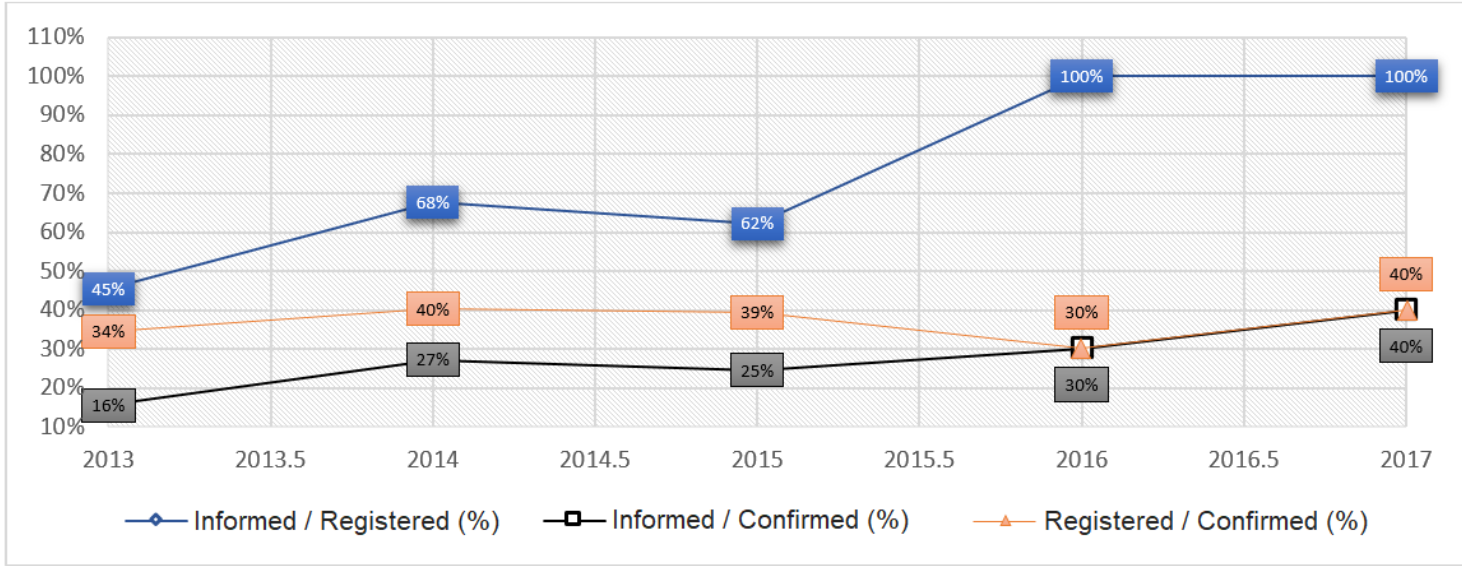


Figure 8 - Total graph of all the analyzed seismic events for the five-year period between the years of 2013 to 2017 for the station SALV, with division by unit of the federation. The event indicated by "--" refers to events occurring outside Brazil.

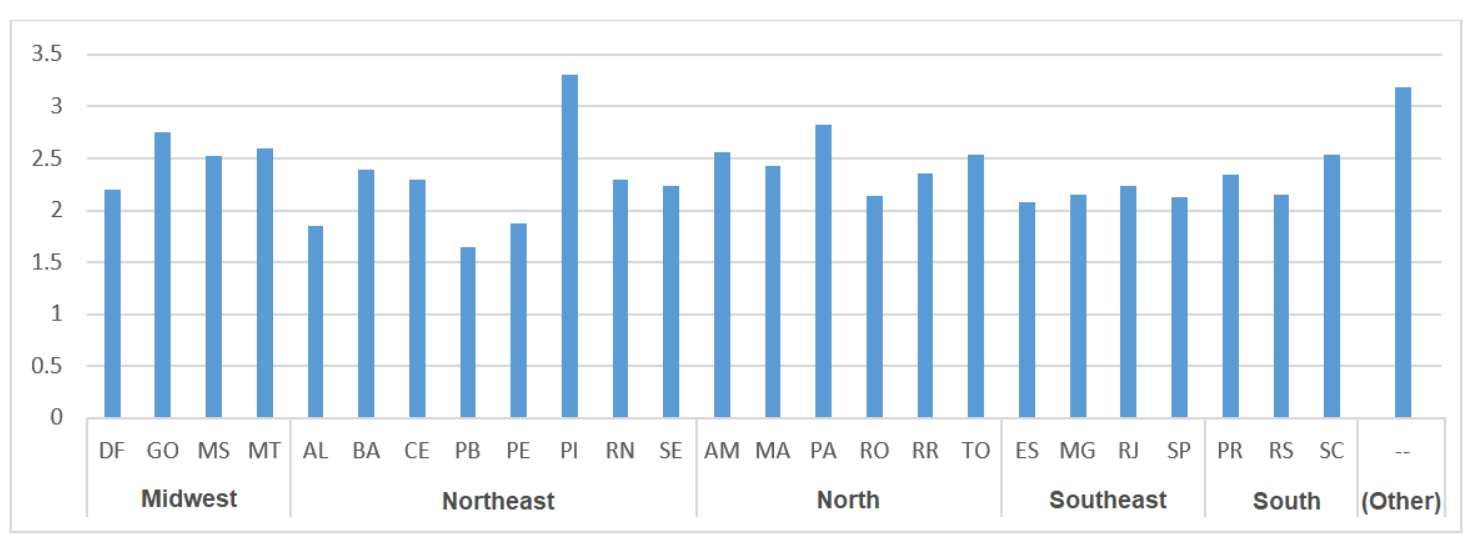

Source: Authors.

From the coordinates of the epicenters of the events, it can be assumed, not knowing their real depth, that the path in the subsurface along which the waves passed is a straight line until arriving at the seismographic station. Thus, by placing the generated seismogram of the event on the map it is possible to infer the approximate locations in which the changes in the physical medium occurred in the propagation of the wave by means of the velocity breaks in the seismogram. The most distant points of the central line (highs) in the seismograms correspond to increases in velocity (larger peaks), where the waves pas sed in more solid (dense) media, which may indicate in this point that the wave reached greater depths in that locality, such as the basement or substrata of the Pantanal Basin.

In this case, it is assumed that the seismographic station registers the event only after the mechanical waves pass through it, considering that the recorded event is the reflected event, then it is necessary to undo this inversion, reflecting again on the horizontal. In this way, when tracing lines that divide the groups, we obtain a "seismic stratigraphy", that is, a strata image through which the seismic wave passed from the epicenter to the station.

The results obtained from the combination of methods described above were superimposed on the boundaries of the Pantanal subregions (Mioto et al., 2012) and it was noted that the records of the events show the structural-geological contacts. The confirmation of this correlation occurred within the QGIS geoprocessing software (QGIS Development Team, 2013), since it allows the seismograms, the geological map, and the subregion map of the Pantanal to be overlain, thus revealing unpublished aspects of the substrata of the Pantanal Basin. The following is a list of the events studied that demonstrate the above scenario. The events are specified from the coding that they received at the time they were recorded in the catalog of seismic events in 2015 (WIJF) and in 2016 (GANC, PWIZ, PVHA, RUXN).

\subsection{Event 01 - WIJF (case study)}

The event USP2015WIJF occurred on November 14, 2015, had a magnitude (M) of 2.4 degrees on the Richter scale, was located at the border between the Pantanal subregions of Miranda-Abobral and Nhecolândia (Mioto et al., 2012), approximately $150 \mathrm{~km}$ from the Municipality of Aquidauana, and occurred at the beginning of the rainy season in the Pantanal. In this event, the velocity changes were marked and separated and its epicenter was located in one of the Pantanal subregions proposed by Mioto et al. (2012). This corresponds to the boundary between the Pantanal subregions of Nhecolândia and Taquari, where the first velocity peak occurred during the seismic waves route in the Pantanal subregion of the Taquari, while there was a continuous deceleration of the same to the Paiaguás. In the Baixo Barão do Melgaço and Canoeira subregions, there was an acceleration up to the Alto Barão do Melgaço, after which the velocity decreased until reaching the station (Figures 9 and 10). 
Figure 9 - Path traveled by the seismic waves generated by the event (represented by the four-pointed star), where the blue line corresponds to the straight line traveled by them until the seismographic station (green triangle). The seismogram with the various recorded waves was divided into seven specific segments (A-G), to facilitate the description of its path.

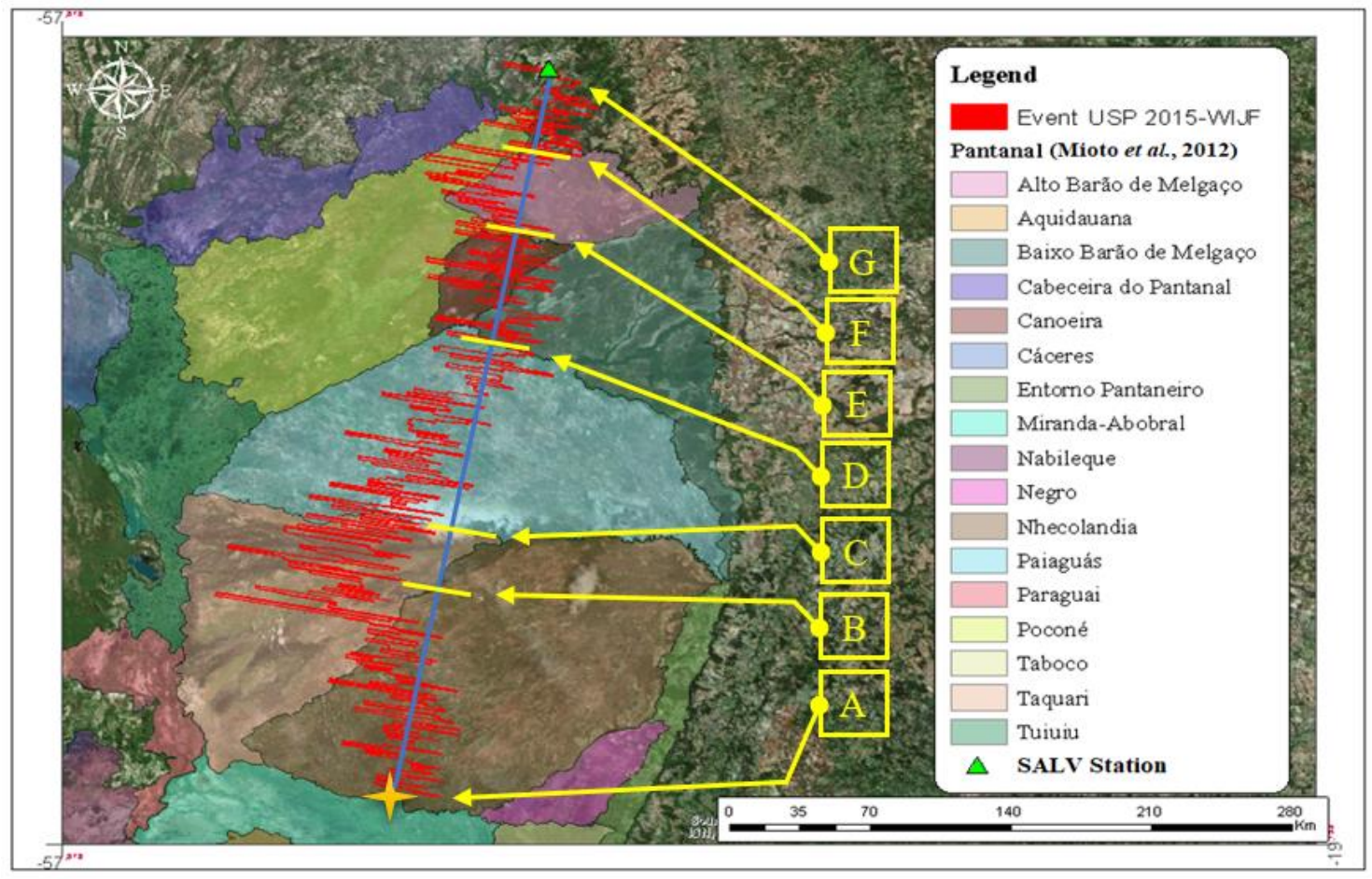

Source: Authors.

Figure 10 - Seismic profile made from the seismogram with the recording of seismic waves generated by a seismological event. This profile starts at the border of Pantanal da Nhecolândia and Miranda - Abobral (A) and shows an increase in speed up to segment B. Between segment B / C (Taquari) there is a continuous deceleration until segment D (Paiaguás). Between the D / E segment (Baixo Barão do Melgaço and Canoeira) there is an increase in speed until segment F (Alto Barão do Melgaço), when it begins to decelerate and gradually decrease the speed until reaching the seismic wave recording station $(\mathrm{G})$.

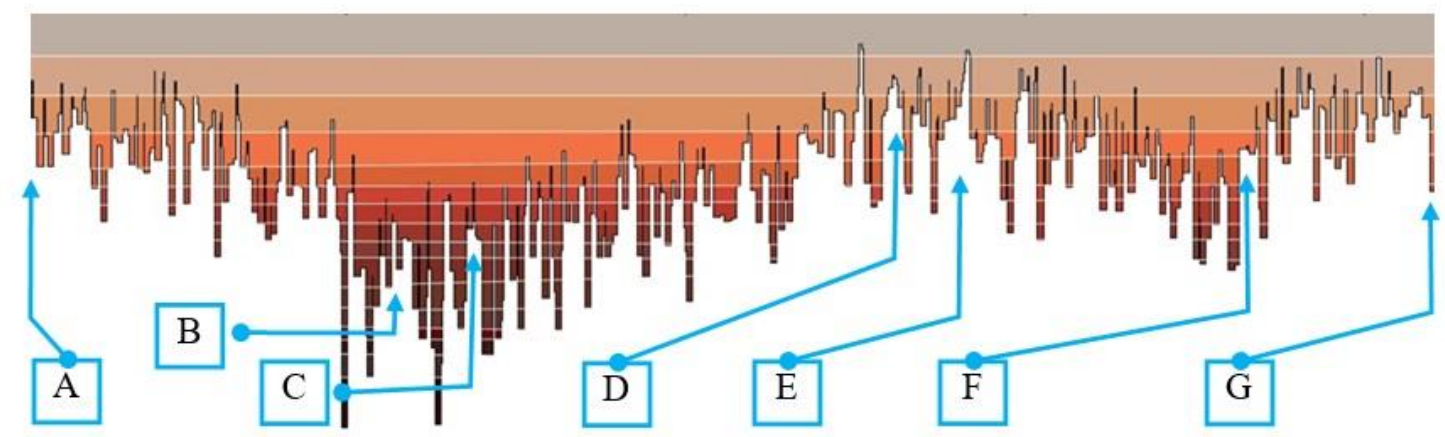

Source: Authors.

\subsection{Event 02 - GANC (case study)}

The USP2016GANC event occurred on March 26, 2016, had a magnitude of 3.1 degrees on the Richter scale, and occurred at the end of the rainy season (full) in the Pantanal. The event was located outside the Pantanal. Its greater distance (relative to the other events) may have affected seismic waves pickup, since the coincidences between the seismic signal and the subregions are very compatible when allowing a small shift to the West. The velocity increased in the Pantanal subregion of 
Nhecolândia, and there was a peak of acceleration at the boundary with the Taquari subregion, after which there a sudden decrease in velocity occurred, which remained relatively constant until the end of the event (Figures 11 and 12).

Figure 11 - Path traveled by the seismic waves generated by the event (represented by the four-pointed star). The blue line corresponds to the straight line taken by the seismic waves to the seismographic station (green triangle). The seismogram was divided into ten specific segments (A-J), to facilitate the description of the seismic wave path.

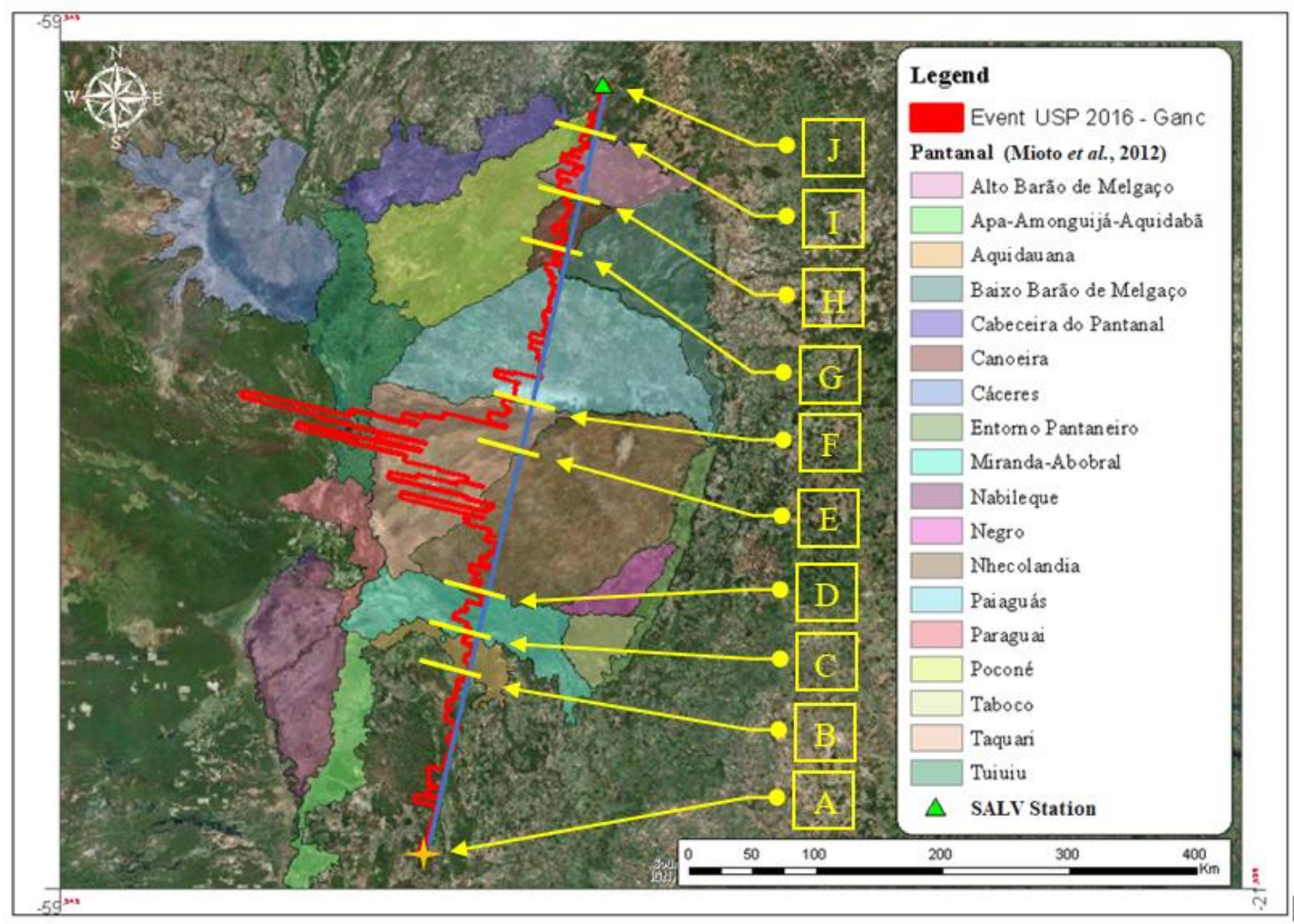

Source: Authors.

Figure 12 - Seismic profile made from the seismogram with the recording of seismic waves generated by a geological event. The event starts (A) and continues with a slight and gradual increase in speed to segment D. In segment D / E (Nhecolândia) there is an exponential gain in speed in segment E, where the Pantanal do Taquari begins, with then a sudden drop in speed, which remains with small speed oscillations until the end of the seismic profile.

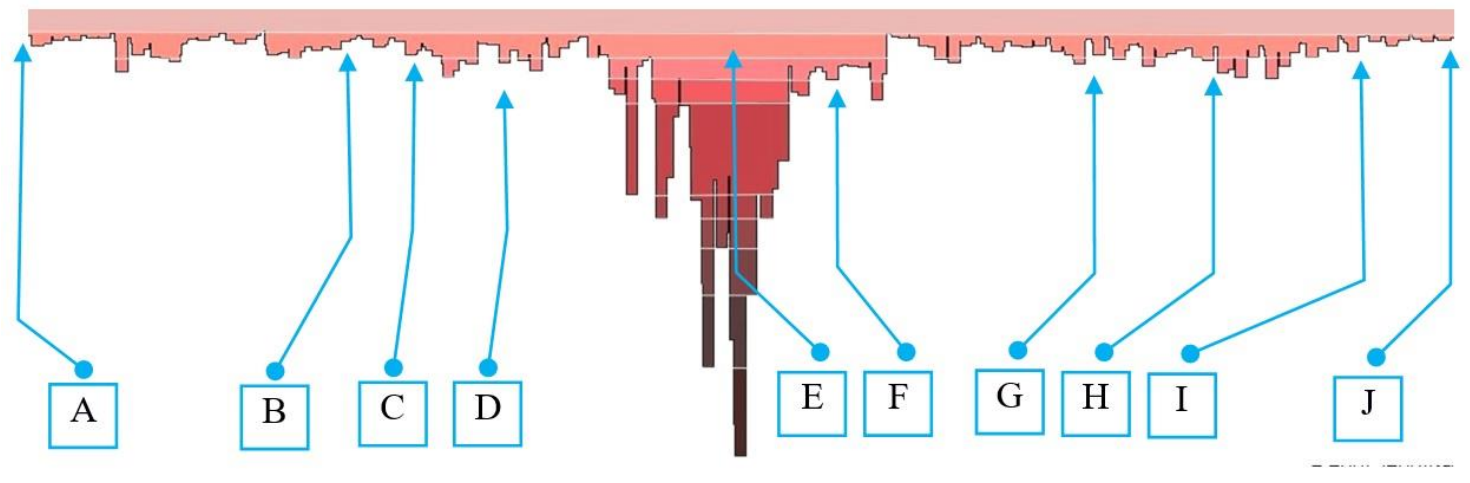

Source: Authors. 


\subsection{Event 03 - PWIZ (case study)}

The USP2016PWIZ event occurred on August 13, 2016, had a magnitude of 2.8 degrees on the Richter scale, and unlike the previous events, occurred during the dry season in the Pantanal. An excellent correspondence between the seismic waves and the subregion substrata was observed with this event. The event began in the subregion of Nhecolândia and increased velocity up to Paiaguás. In the Canoeira subregion, acceleration peaks could be visualized. There was an increase in the velocity between the subregions of Poconé and Alto Barão do Melgaço, followed by a sudden decrease until reaching the SALV station (Figures 13 and 14).

Figure 13 - Path traveled by the seismic waves generated by the event (represented by the four-pointed star), where the blue line corresponds to the straight line traveled by them to the recording station (green triangle). The seismogram was divided into seven specific segments (A-I), to facilitate the description of the seismic wave path.

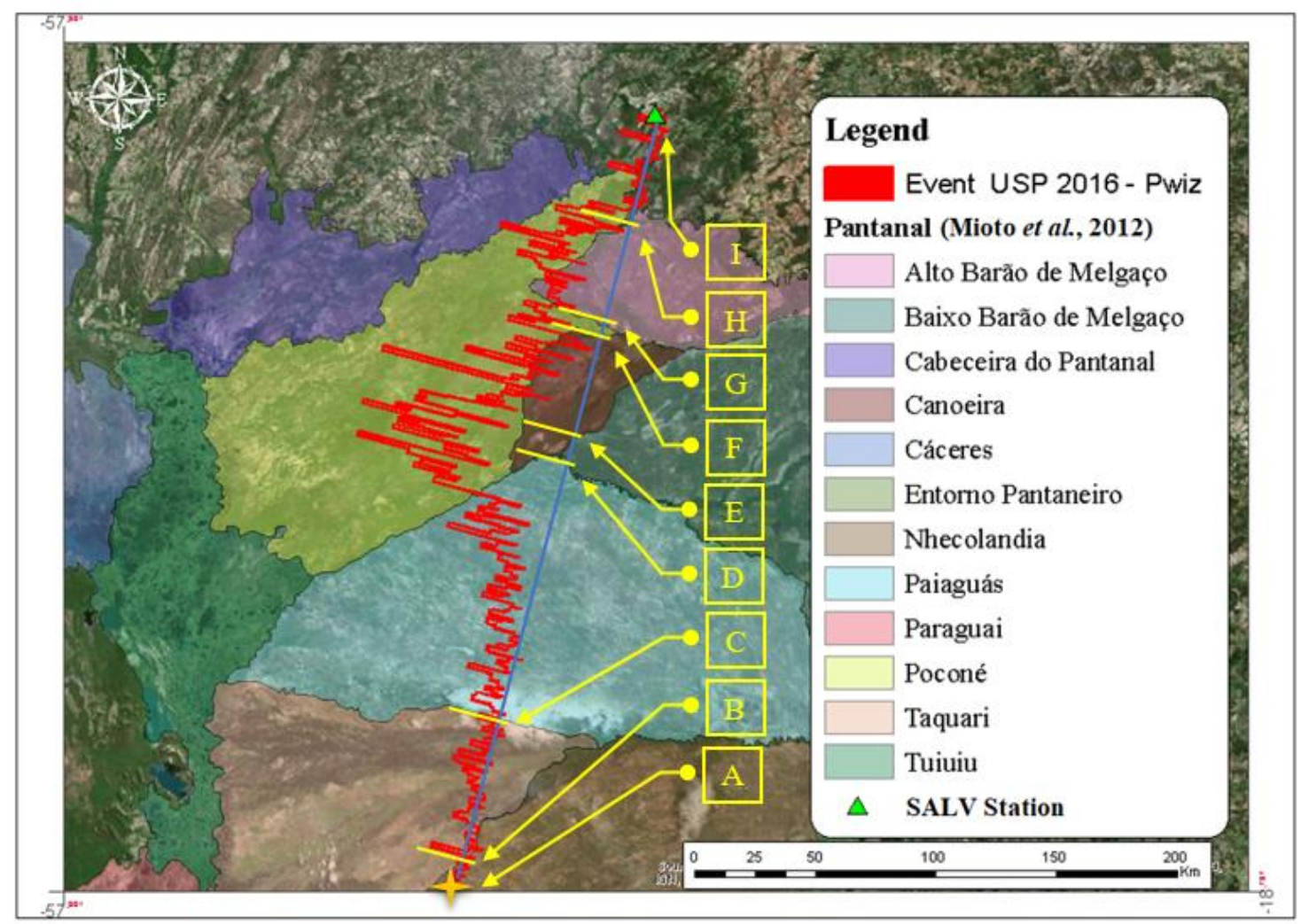

Source: Authors. 
Figure 14 - Seismic profile made from the seismogram with the recording of seismic waves generated by a geological event. This profile starts at point A (Nhecolândia) and the speed increases slowly at first and then quickly until segment D (Paiaguás). Between the E-F (Canoeira) segments, acceleration peaks are seen, which repeat before reaching F, but the trend is the deceleration. In the F-H segment (Poconé and Alto Barão do Melgaço) there is a tendency to increase speed and then decrease sharply until the end of segment I and the Santo Antônio do Leverger station.

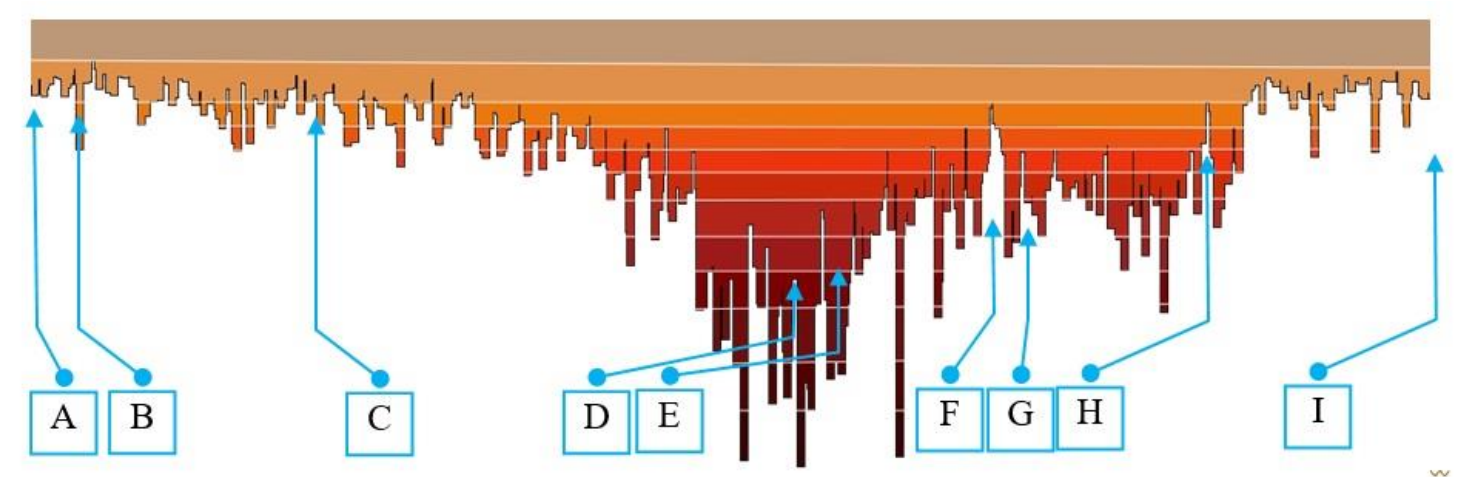

Source: Authors.

\subsection{Event 04 - PVHA (case study)}

The USP2016PVHA event occurred on August 13, 2016, had a magnitude of 3.1 degrees on the Richter scale, and occurred right in the middle of the Pantanal dry season. The event began in the subregion of Nhecolândia with a low velocity and gained acceleration along the subregions until the subregion of Baixo Barão do Melgaço. There was a sudden deceleration in the subregion of Canoeira, sudden deceleration occurs, followed by a continuous deceleration in the subregion of Alto Barão do Melgaço and to the edge of the Pantanal. A further abrupt deceleration occurred at the edge of the Pantanal before the signal reached the seismographic station (Figures 15 and 16). 
Figure 15 - Path traveled by the seismic waves generated by the event (represented by the four-pointed star), where the blue line corresponds to the straight line traveled by them to the seismographic station (green triangle). The seismogram was divided into seven specific segments (A-I), to facilitate the description of the seismic wave path.

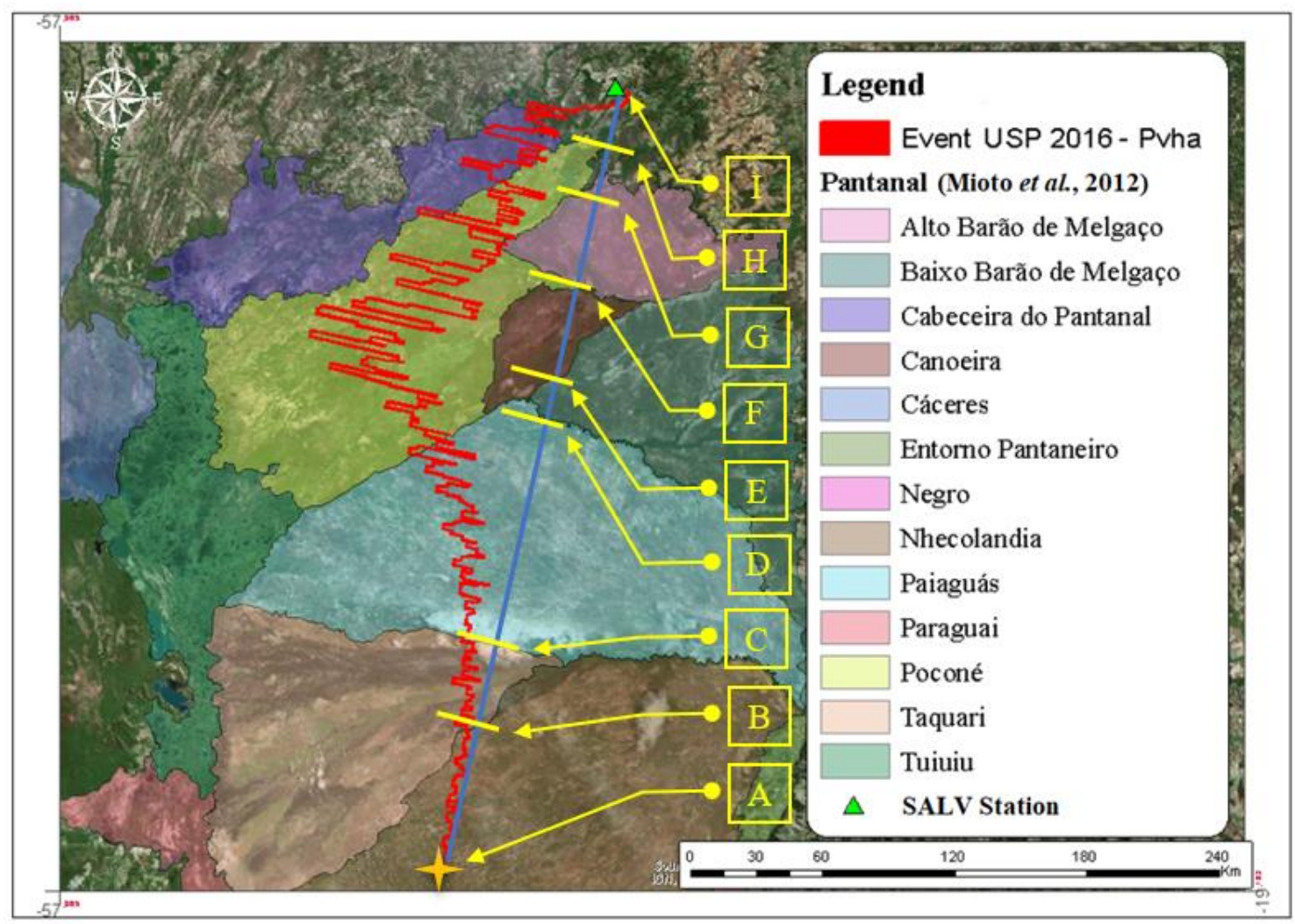

Source: Authors.

Figure 16 - Seismic profile made from the seismogram with the recording of seismic waves generated by a geological event. This profile starts at point A (Nhecolândia), with little energy and with each phase change it reaches greater acceleration until the D-E segment (Baixo Barão do Melgaço), where it presents peaks of acceleration. Between the E-F segment (Canoeira) there is a relatively sudden deceleration. In the F-H segment (Alto Barão do Melgaço and Pantaneira border), the deceleration is continuous, with some acceleration peaks, while in the H-I segment there is a very sudden deceleration until reaching the SALV station.

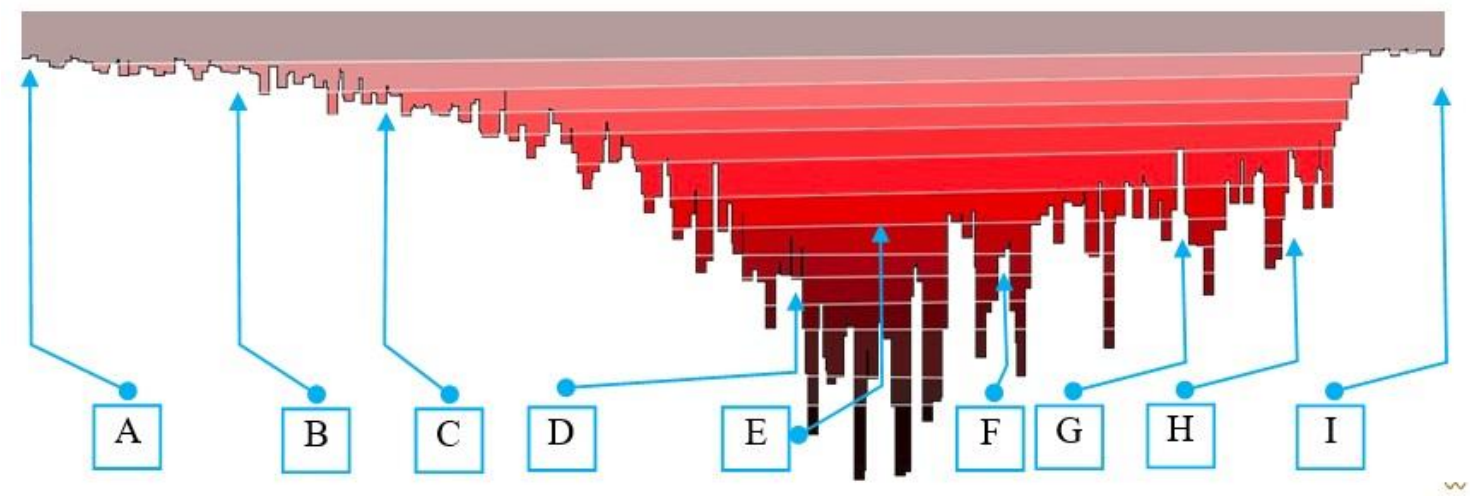

Source: Authors. 


\subsection{Event 05 - RUXN (case study)}

The USP2016RUXN event occurred on September 10, 2016, had a magnitude of 2.4 degrees on the Richter scale, and occurred at the end of the Pantanal dry season. The event began in the subregion of Entorno Pantaneiro, with a slight increase in velocity between the subregions of Negro and Nhecolândia. There's an acceleration increased as the signal passed through the Paiaguás subregion and decreased as it passed through the Baixo Barão de Melgaço, showing the slowly decelerating in the Alto Barão de Melgaço subregion until it reached the SALV seismographic station (Figures 17 and 18).

Figure 17 - Path traveled by the seismic waves generated by the event (represented by the four-pointed star), where the blue line corresponds to the straight line traveled by them to the seismographic station (green triangle). The seismogram was divided into seven specific segments (A-H), to facilitate the description of the seismic wave path.

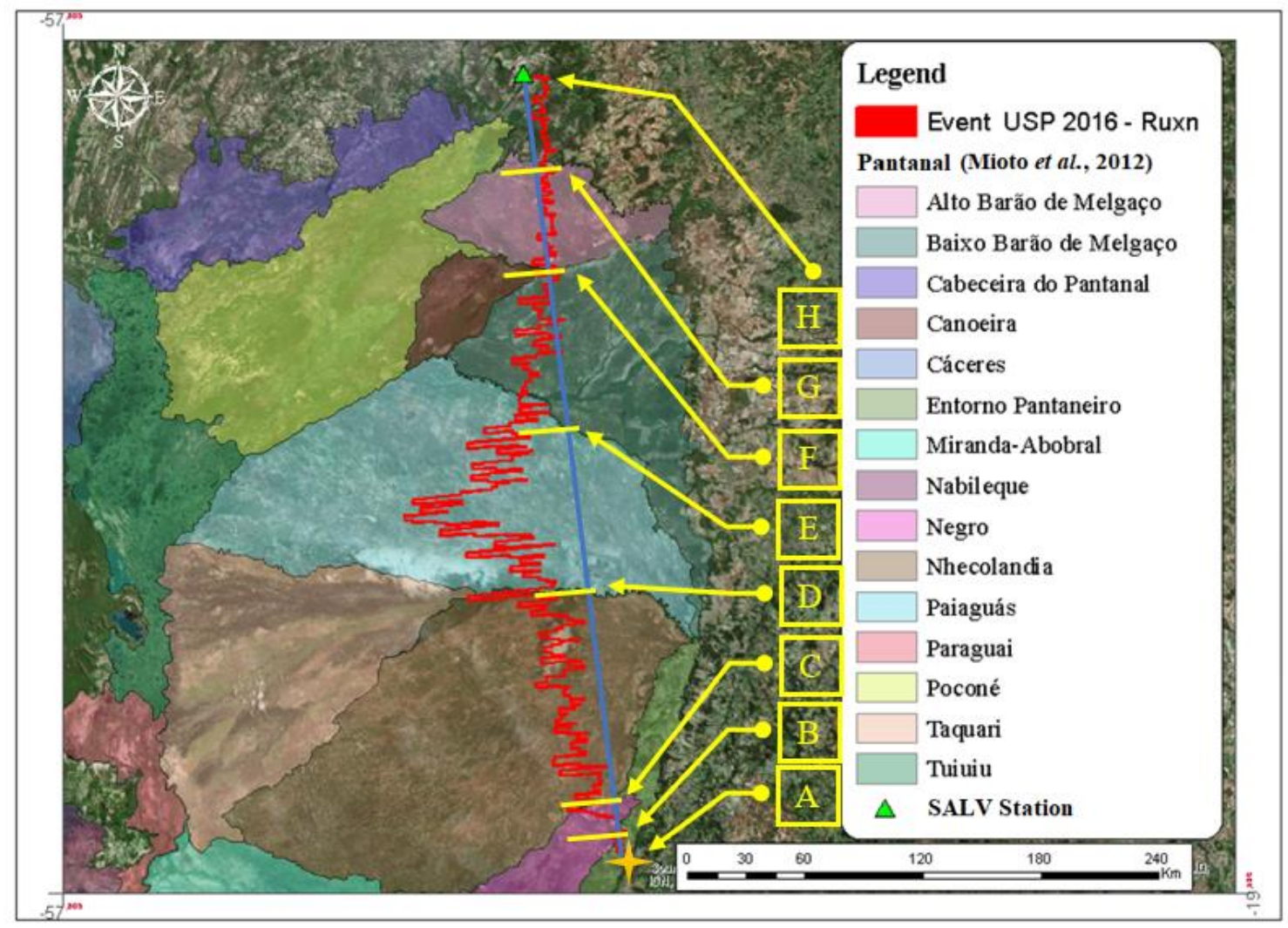

Source: Authors. 
Figure 18 - Seismic profile made from the seismogram with the recording of seismic waves generated by a geological event. This profile starts in the Sub-region of the Entorno Pantaneiro (A), with a slight increase in speed between the B-C-D segments (Negro and Nhecolândia). Between the D-E segments the speed increases and then decelerates rapidly when passing through the Paiaguás sub-region. The acceleration decreases when passing through the Baixo Barão de Melgaço sub-region (Segment E-F) and remains slowly decreasing as it crosses the Alto Barão de Melgaço sub-region to SALV station (Segment F-G-H).

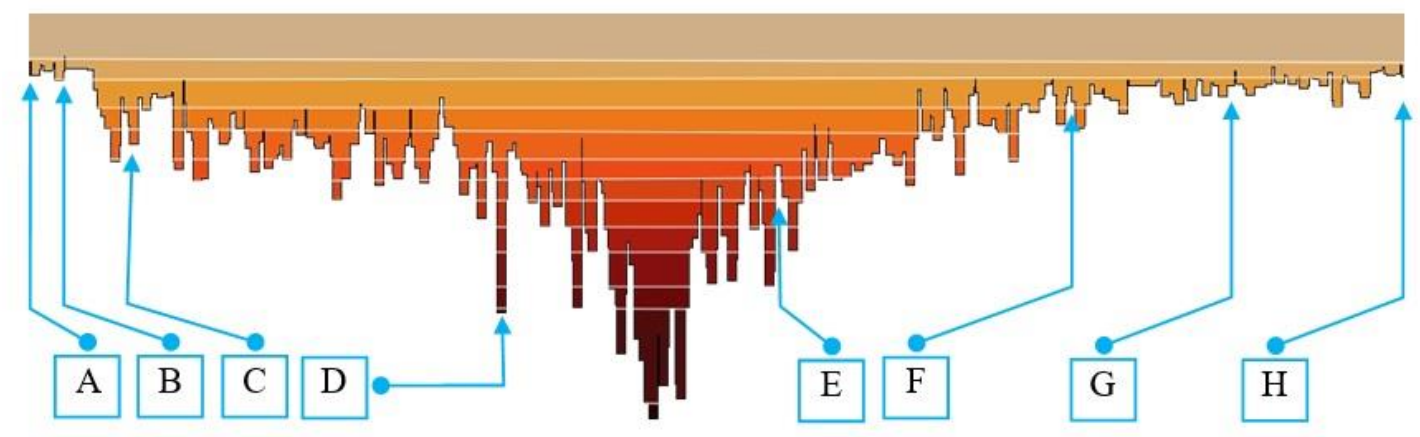

Source: Authors.

\section{Final Considerations}

From the analysis of pure seismograms it was possible to separate different speed clusters, referred to as groups or phases. The speed of seismic waves increases or decreases, depending on the medium in which it passes. In a sedimentary basin, the sudden change in depth of the behavior of seismic waves, longitudinal or primary ( $\mathrm{P}$ waves) and transverse or secondary ( $\mathrm{S}$ waves), may indicate the presence of the basin's substrate, since the waves penetrate a material of greater density. On the other hand, the behavior of elastic waves is slower and has difficulties when crossing sediments in the basin. In addition to its lower density, this is also due to its porous structure, since these are predominantly sandy and porous sediments, which makes it difficult to propagate the waves. The association between the thick package of sediments in the Pantanal Basin and the large amount of water contained in them creates a complicated scenario for the transmission of seismic waves, making it difficult to study the basin's tectonics. It is known, however, that elastic waves need a solid medium to propagate, which is why, by inverting the seismogram, depth is obtained.

The development of the activities described above, and the results achieved, showed that of the total number of recorded events, few of those traversed the Pantanal Basin. A total of 39 events have been confirmed so far.

The distinct behavior of the seismic waves in each subregion of the Pantanal can be explained by the differences in composition, geometry, and thickness of the sediment layers that make up the sedimentary packages in these subregions. Although each one of them presents an independent behavior for each event analyzed, there are subregions that tend to refract or diffract seismic waves more or less similarly, such as in the regions of Taquari, Canoeira, and Alto Barão de Melgaço, where there is a trend in the increase in the speed of seismic waves, while in the Nhecolândia region, this behavior is the opposite, that is, it shows a decrease in speed of the referred waves.

\section{Acknowledgments}

The authors would like to thank the Foundation of the Federal University of the State of Mato Grosso do Sul and the CNPq for the granting of the Scientific Initiation Grant to Amanda Letícia Abegg da Silveira. We would also like to thank the Foundation for Support to the Development of Education, Science and Technology of the State of Mato Grosso do Sul FUNDECT, for granting the Regional Scientific Development Grant awarded to Gustavo Marques and Amorim (TO 140/2014), 
and CNPq for the Research Productivity Grants awarded to Antonio Conceição Paranhos Filho (case 304 122/2015-7) and Rômulo Machado (case 300423/82-9). This study was financed in part by the Coordenação de Aperfeiçoamento de Pessoal de Nível Superior - Brasil (CAPES) - Finance Code 001.

To CAPES for the granting of a doctoral scholarship by Dhonatan Diego Pessi, case number 88887.494036/2020-00.

They also thank the Federal University of Mato Grosso do Sul.

\section{References}

Almeida, F. F. M. (1945). Geologia do Sudoeste Matogrossense. Boletim. Divisão de Geologia e Mineralogia, DNPM. 118p.

Almeida, F. F. M. (1965). Geologia da Serra da Bodoquena (Mato Grosso). Boletim. Divisão de Geologia e Mineralogia, DNPM, 96p.

Assine, M. L., \& Soares, P. C. (2004). Quaternary of the Pantanal, west-central Brazil. Quaternary International, 114, 23-34.

Assine, M. L. et al. (2015). Geology and geomorphology of the Pantanal basin. In: Dynamics of the Pantanal Wetland in South America. Springer, Cham, 2350 .

Assumpção, M. et al. (2016). Intraplate stress field in South America from earthquake focal mechanisms. Journal of South American Earth Sciences, 71, 278295.

Branner, J. C. (1912). Earthquakes in Brazil. Bulletin of the Seismological Society of America, 2(2), 105-117.

Brasileira, R. S. (2015). Rede Sismográfica Brasileira.

Collaço, B. (2016). Python ObsPy Earthquake Tool Script. Instituto de Astronomia e Geofísica - IAG: Universidade de São Paulo - USP.

Dias, F. L., Assumpção, M., Facincani, E. M., França, G. S., Assine, M. L., Paranhos Filho, A. C., Gamarra, R. M. (2016). The 2009 earthquake, magnitude mb 4.8, in the Pantanal Wetlands, west-central Brazil. Anais da Academia Brasileira de Ciências, 88(3), p. 1253-1264.

Facincani, E. M., Assumpção, M., Assine, M. L., \& França, G. S. L. A. (2011). Sismicidade da Bacia Sedimentar do Pantanal. In: 13 Simpósio Nacional de Estudos Tectônicos e VII International Symposium on tectonic, 2011, Campinas-Unicamp, 1. p. 314-317.

Facincani, E. M., Assumpção, M. S., Assine, M. L., França, G. S. L. A., Paranhos Filho, A. C., \& Gamarra, R. M. (2012). Terremotos no Pantanal. In: FERREIA, F. M. N. S. et al. (Org.). Pantanal: perspectivas históricas e culturais. Campo Grande, MS: Editora UFMS, p. 87-99.

Freitas, R. O. de. (1951). Relevos policíclicos na tectônica do escudo brasileiro. Boletim Paulista de Geografia, .7, $03-19$.

Litherland, M. et al. (1989). The Proterozoic of eastern Bolivia and its relationship to the Andean mobile belt. Precambrian Research, 43(3), $157-174$.

Lomax, A. (2011). SeisGram2K Seismogram Viewer.

Mioto, C. L., Paranhos Filho, A. C., \& Albrez, E. D. A. (2012). Contribuição à caracterização das sub-regiões do Pantanal. ENTRE-LUGAR, 3(6), 165-180.

NANOMETRICS. (2010). Taurus NMX - Technical Specifications.

NASA. (2013). Landsat 8. http://www.nasa.gov/mission_pages/landsat/spacecraft/index.html\#.UieDrzY3s0M.

Oliveira, A. P. G., Machado, R., Ribeiro, A. A., Mioto, C. L., Marcato, J. R. J., Saad, A. R., Sígolo, J. B., \& Paranhos Filho, A. C. (2018). The expression of neotectonics in the Pantanal da Nhecolândia, State. of Mato Grosso do Sul - Brazil, Anais da Academia Brasileira de Ciências, 90(2), $1293-1308$.

Paranhos Filho, A. C., Aamorim, G. M. E., Machado, R., Marcato, J., Prol, F. D. S., Oliveira, J. R. S. D., \& Mioto, C. L. (2018). Geodesia as a support tool for the pantanal neotectonics understanding:. The corumbá fluviometric station example, mato grosso do sul, Brazil. Anuario do Instituto de Geociencias, 16-23.

Paranhos Filho, A. C., Nummer, A. R., Albrez, E. A., Ribeiro, A. A., \& Machado, R. (2013). A study of structural lineaments in Pantanal (Brazil) using remote sensing data. Anais da Academia Brasileira de Ciências, 85(3), 913-922.

Pirchiner, M. I. et al. (2011). The Brazilian Seismographic Integrated Systems (BRASIS): infrastructure and data management. ANNALS OF GEOPHYSICS, 54(1), 17-22.

QGIS Development Team. (2012). Quantum GIS geographic information system. Open source geospatial foundation project. Free Software Foundation, India.

Riccomini, C., \& Assumpção, M. (1999). Quaternary tectonics in Brazil. Episodes, 22, 221-225.

RGEOTEC. (2012). Rede Sismográfica Brasileira. 1, Rio de Janeiro. <http://www.rsbr.gov.br/index.html>.

Selesnick, I. W., \& Burrus, C. S. (1998). Generalized digital Butterworth filter design. Signal Processing, IEEE Transactions on, 46(6), 1688-1694.

Schobbenhaus, C., Ribeiro, C. L., Oliva, L. A., Takanohashi, J. T., Lindenmayer, Z. G., Vasconcelos, J. B., \& Orlandi, V. (1975). Folha Goiás (SD-22). In: Carta Geológica do Brasil ao Milionésimo, Brasília: DNPM, 113 p. 
Research, Society and Development, v. 10, n. 9, e57710918243, 2021

(CC BY 4.0) | ISSN 2525-3409 | DOI: http://dx.doi.org/10.33448/rsd-v10i9.18243

SISMOGRÁFICA, R. (2004). BLSP02: Projeto de Estudo Sismológico da Crosta e Manto Superior no Brasil.

Soares, P. C., Assine, M. L., \& Rabelo, L. (1998). The Pantanal Basin: recent tectonics, relationships to the Transbrasiliano Lineament. In: Anais IX Simpósio Brasileiro de Sensoriamento Remoto, 459-469.

Sousa, F. J. (2017). Revisão da geologia da porção SW do estado de Mato Grosso, S do estado de Rondônia e do leste da Bolívia. Revista Brasileira de Geociências, 21(1), p. 74-81.

Thomas, K., Sicam, J., Chanelle, A., Thomas, A., \& Sicam, C. (2009). Beginning Ubuntu Linux. Apress, 800p.

USP, U.D.S.P. (2013). Boletim Sísmíco Brasileiro - Centro de Sismologia. p. Boletim Sísmico Brasileiro. <http://www.moho.iag.usp.br/rq/> .

Ussami, N., \& Shozo, S. (1999). Basement reactivation in as Sub-Andean foreland flexural bulge: the Pantanal, SW Brazil. Tectonics, 18(1), 25-39.

Ussami, M. et al. (2000). Investigações geofísicas integradas na planície do Pantanal Matogrossense: implicações tectônicas e hidrogeológicas de subsuperfície. Proceedings of the Third Simpósio de Recursos Naturais e Sócio-Econômicos do Pantanal. Embrapa, Pantanal, Corumbá, Brasil. 125p. 